\title{
Effects of Planting Date on Fiber Digestibility of Whole-Crop Barley and Productivity of Lactating Dairy Cows
}

\author{
L. O. Chow, ${ }^{*}$ V. S. Baron, $†$ R. Corbett, $\neq$ and M. Oba*1 \\ *Department of Agricultural, Food and Nutritional Science, University of Alberta, Edmonton, Alberta, T6G 2P5, Canada \\ †Agriculture and Agri-Food Canada, Lacombe, Alberta, T4L 1W1, Canada \\ $\ddagger$ Alberta Agriculture and Food, Edmonton, Alberta, T6H 5T6, Canada
}

\section{ABSTRACT}

Objectives of the study were to evaluate the effect of planting date on in vitro neutral detergent fiber digestibility (IVFD) of whole-crop barley (Hordeum vulgare) and its effects on productivity of lactating dairy cows. Two cultivars of barley were planted on May 5 (BM) and June 7 (BJ), 2005 at the Edmonton Research Station, University of Alberta. They were harvested at latedough stage on July 26 and August 25, respectively, for BM and BJ and ensiled. The BJ had greater 30-h IVFD (61.2 vs. $51.9 \%)$ and crude protein concentration (12.4 vs. $8.7 \%)$ at harvest compared with BM. Thirty lactating cows, including 6 ruminally cannulated cows, in mid to late lactation (183 $\pm 71.7 \mathrm{~d}$ in milk; mean \pm standard deviation) were fed diets containing BM or BJ at $58.5 \%$ of dietary DM in a crossover design with 19-d periods. The dietary neutral detergent fiber concentration was 30.6 and $28.8 \%$ for BM and BJ diets, respectively. Dry matter intake and milk yield were not affected by treatment and averaged 20.2 and $27.2 \mathrm{~kg} /$ $\mathrm{d}$, respectively. The lack of responses could have been attributed to the low-energy demands for cows used in this experiment; ruminal physical fill might not have limited dry matter intake. However, cows fed BJ had greater total tract dry matter digestibility (68.9 vs. $66.1 \%$ ) and tended to increase body weight gain (864 vs. $504 \mathrm{~g} / \mathrm{d}$ ) compared with those fed BM. Delaying the planting date of barley altered its growing environment and affected nutrient composition and IVFD of wholecrop barley and energy availability to animals. Further research is needed to confirm if the planting date consistently affects nutrient composition and IVFD of barley at harvest.

Key words: barley, planting date, fiber digestibility, milk production

Received November 12, 2007.

Accepted December 14, 2007.

${ }^{1}$ Corresponding author: masahito.oba@ualberta.ca

\section{INTRODUCTION}

Maximizing DMI is important in nutritional management of lactating dairy cows. Greater DMI can increase milk yield and reproductive performance and reduce the risk of metabolic diseases due to the negative energy balance caused by high energy demands during early lactation (Grummer et al., 1995). However, dairy cows require adequate fiber to maintain healthy rumen function, because the amount of forage NDF largely determines the amount of chewing activity and hence salivary buffer secretion (Allen, 1997). Reducing dietary fiber decreases chewing and salivary production, which increases the risk of ruminal acidosis and milk fat depression and reduces fiber digestion (Beauchemin and Rode, 1997). However, fiber ferments slowly and is retained in the rumen longer than nonfiber fractions, which distends the reticulorumen and limits DMI (Dado and Allen, 1995; Allen, 1996).

It has been suggested that DMI be predicted based on the dietary NDF content due to the negative relationship between DMI and NDF content (Mertens, 1987). However, NDF varies in degradability in the rumen, ranging from less than $35 \%$ to over $75 \%$ for different forage types (Nocek and Russell, 1988), and also varies within fiber sources (Llamas-Lamas and Combs, 1990; Robinson and McQueen, 1992). Enhanced in vitro NDF digestibility (IVFD) can increase DMI due to the greater rate of NDF clearance from the rumen, creating additional space for further intake (Dado and Allen, 1995). Through a statistical analysis of 13 sets of forage comparisons, Oba and Allen (1999a) found that for every 1-unit increase in IVFD or in situ NDF digestibility, DMI and $4.0 \%$ FCM yield increased by 0.17 and 0.25 $\mathrm{kg} / \mathrm{d}$, respectively. The positive effects of enhanced IVFD on DMI and milk yield were reported for corn silage (Oba and Allen, 1999b; Ballard et al., 2001; Ivan et al., 2005), sorghum silage (Grant et al., 1995; Aydin et al., 1999), and alfalfa silage (Dado and Allen, 1996).

Barley silage is the primary forage used by dairy producers in western Canada, but the effects of IVFD of barley silage on performance of lactating dairy cows 
have not been extensively evaluated. Growing environment generally affects forage IVFD; high temperature decreases fiber digestibility by greater lignin synthesis (Fahey and Hussein, 1999). Although the growing environment of barley can be manipulated by altering the planting date, its effects on IVFD have not been investigated. Thus, specific objectives of the present study were to evaluate the effect of planting date on IVFD of whole-crop barley and its effects on DMI and milk production of dairy cows. It was hypothesized that barley planted in June would have lower IVFD compared with that in May, if harvested at the late-dough stage, due to the higher environmental temperature during the growing period. It was also hypothesized that barley silage with enhanced IVFD would increase DMI and milk production of dairy cows.

\section{MATERIALS AND METHODS}

\section{Forage Study}

Two cultivars of barley (Hordeum vulgare), AC Lacombe and Vivar, were planted on May 5, 2005 (BM) and June 7, 2005 (BJ) in 12.4-ha fields at the Edmonton Research Station, University of Alberta. Seeding rate was $112 \mathrm{~kg} / \mathrm{ha}$. In the fall before planting, $78.6 \mathrm{~kg}$ of $\mathrm{N} / \mathrm{ha}$ was applied in a band $24 \mathrm{~cm}$ apart and $10 \mathrm{~cm}$ in the ground to all fields. At planting, a mixture of fertilizers $(16.8 \mathrm{~kg}$ of N/ha, $22.5 \mathrm{~kg}$ of P/ha, $7.9 \mathrm{~kg}$ of S/ ha, and $7.9 \mathrm{~kg}$ of $\mathrm{K} / \mathrm{ha}$ ) was placed in the seed rows with the seeds. DyVel herbicide, which included dicamba as dimethylamine salt and 4-chloro-o-tolyloxyacetic acid as potassium salt, was applied once at $1.2 \mathrm{~L} / \mathrm{ha}$ with the appearance of 4 leaves on the barley plants for broadleaf weed control. For both cultivars, heading dates were July 5 and July 26, and harvest dates were July 26 and August 25, respectively, for BM and BJ.

Daily mean temperature and precipitation data for the past $20 \mathrm{yr}$ (1987 to 2006) for the corresponding growing periods of barley evaluated in the present study (2005) were collected from the University of Alberta (Environmental Canada, 2006; Table 1). Four samples of whole plants were collected weekly from each field after the plant reached the heading stage until they were harvested at the late-dough stage. Samples were collected from a row of 30 to $60 \mathrm{~cm}$, and stands were cut at $1 \mathrm{~cm}$ above the ground. Samples were collected on July 8, 15, and 22 for BM and July 26, August 2, 9, 16, and 23 for BJ.

Forage samples collected before the animal study were sent to Cumberland Valley Analytical Service (Hagerstown, MD) to determine concentrations of NDF (Van Soest et al., 1991), ADF (AOAC, 2000; method 973.18), CP (AOAC, 2000; method 990.03), starch (Holm et al., 1986), and 30-h IVFD (Tilley and Terry,
1963). Data were analyzed using the ANOVA procedure of JMP (version 5.1, SAS Institute Inc., Cary, NC) with the fixed effect of planting date (BM vs. BJ; $n=2$ for each planting date; 2 cultivars were used as experimental units).

\section{Animal Study}

The Vivar barley, both BM and BJ, were used for the animal study after they were harvested at late-dough stage, packed into Agbags, and allowed to ferment for at least $7 \mathrm{wk}$. The NDF, 30-h IVFD, and starch concentrations of Vivar barley silage were $43.7 \pm 0.4,45.5 \pm$ 1.5 , and $25.3 \pm 0.2 \%$ for $\mathrm{BM}$ and $38.0 \pm 0.4,50.3 \pm 1.5$, and $25.2 \pm 0.2 \%$ for BJ, respectively (mean $\pm \mathrm{SD}$; Table 2). Sixteen multiparous and 14 primiparous Holstein cows in mid to late lactation (183 \pm 71.7 DIM; mean \pm SD) were used at the University of Alberta Dairy Research and Technology Center. Although cows in early lactation would be a better model to test the hypothesis, they were used for another experiment and not available for this study. Six of the multiparous cows were ruminally cannulated before the study. Cows were randomly assigned to 1 of 2 experimental diets after they were blocked by parity within a crossover design. At the beginning of the experiment, cows averaged 591 $\pm 68 \mathrm{~kg}$, and BCS was $2.98 \pm 0.31$ (mean \pm SD). Treatment periods were $19 \mathrm{~d}$, with the final $5 \mathrm{~d}$ used as a collection period. Cows were housed in tie stalls throughout the experiment except for $2 \mathrm{~h}$ of daily exercise. Cows were cared for according to the guidelines of the Canadian Council on Animal Care (Institutional Animal Use Approval Number: experiment 2005-12$\mathrm{CO})$.

Experimental diets were fed as TMR and contained either BM or BJ Vivar silage (58.5\% dietary DM), dryrolled barley grain, corn gluten meal, and a premix of minerals and vitamins. Because the BM had lower CP, the BM diet also included canola meal and urea in place of beet pulp in the BJ diet so that the diets would be isonitrogenous. The nutrient composition of the diets was $19.7 \pm 0.2 \% \mathrm{CP}$ and $30.6 \pm 0.9 \% \mathrm{NDF}$ for $\mathrm{BM}$ and $20.0 \pm 0.8 \% \mathrm{CP}$ and $28.8 \pm 0.4 \% \mathrm{NDF}$ for BJ (mean $\pm \mathrm{SD}$; Table 3). All diets were formulated to meet or exceed all the nutrient requirements according to the Dairy NRC (NRC, 2001).

Cows were fed once daily $(1100 \mathrm{~h})$ at $110 \%$ of expected intake. The amount of feed offered and orts were weighed and recorded daily during the collection period. Samples of dietary ingredients $(0.5 \mathrm{~kg})$ and orts $(10 \%)$ were collected daily during the collection period and pooled into 1 sample per cow per period. The DM content of the barley silage was determined weekly to adjust dietary allocation of forages to ensure a consistent 
Table 1. Average daily mean temperature and precipitation from 1987 to 2006 for the corresponding growing periods of barley evaluated in the present study ${ }^{1}$

\begin{tabular}{|c|c|c|c|c|}
\hline \multirow[b]{2}{*}{ Item } & \multicolumn{2}{|c|}{$\mathrm{BM}^{2}$} & \multicolumn{2}{|c|}{$\mathrm{BJ}^{3}$} \\
\hline & Mean & $\mathrm{SD}$ & Mean & $\mathrm{SD}$ \\
\hline \multicolumn{5}{|l|}{ Planting to heading } \\
\hline Average daily mean temperature,${ }^{4} \mathrm{C}$ & 13.4 & 0.06 & 16.2 & 0.75 \\
\hline Average precipitation, $\mathrm{mm} / \mathrm{d}$ & 2.5 & 0.60 & 3.1 & 0.48 \\
\hline \multicolumn{5}{|l|}{ Heading to harvest } \\
\hline Average daily mean temperature, ${ }^{\circ} \mathrm{C}$ & 17.4 & 1.04 & 16.6 & 1.67 \\
\hline Average precipitation, $\mathrm{mm} / \mathrm{d}$ & 2.8 & 0.02 & 2.6 & 0.60 \\
\hline \multicolumn{5}{|l|}{ Planting to harvest } \\
\hline Average daily mean temperature,${ }^{4} \mathrm{C}$ & 14.5 & 0.33 & 16.4 & 1.10 \\
\hline Average precipitation, $\mathrm{mm} / \mathrm{d}$ & 2.6 & 0.47 & 2.9 & 0.07 \\
\hline
\end{tabular}

${ }^{1}$ Data at University of Alberta were collected from Environmental Canada (2006).

${ }^{2}$ Barley planted on May 5, 2005. Planting, heading, and harvest dates were May 5, July 5, and July 26, respectively, for barley evaluated in the present study.

${ }^{3}$ Barley planted on June 7, 2005. Planting, heading, and harvest dates were June 7, July 26, and August 25 , respectively, for barley evaluated in the present study.

${ }^{4} \mathrm{BM}$ and BJ means differ $(P<0.01)$.

forage:concentrate ratio. Cows were milked twice per day in the tie stalls at 0600 and $1600 \mathrm{~h}$. Milk yield was measured daily during the collection period and averaged over the 5-d collection period. Milk was sampled from both milkings on d 15, 17, and 19. Body weight was recorded on 2 consecutive days immediately before the start of the first period and on the last $2 \mathrm{~d}$ of each period. Body condition score, on a scale of 1 to 5 ( $1=$ thin and $5=$ fat; Wildman et al., 1982), was determined by 2 trained investigators $1 \mathrm{~d}$ before the first period and on the last day of each period. Fecal and blood samples were collected from each cow every $16 \mathrm{~h}$ for 4 $\mathrm{d}(\mathrm{n}=4$ per period), representing every $6 \mathrm{~h}$ of a $24-\mathrm{h}$ period to account for diurnal variation. Fecal samples $(150 \mathrm{~g})$ were collected from the rectum, frozen at $-20^{\circ} \mathrm{C}$, and composited into 1 sample per cow per period imme-

Table 2. Nutrient composition and particle size of freshly chopped and ensiled Vivar barley used in experimental diets

\begin{tabular}{|c|c|c|c|c|}
\hline \multirow[b]{2}{*}{ Item } & \multicolumn{2}{|c|}{$\mathrm{BM}^{1}$} & \multicolumn{2}{|c|}{$\mathrm{BJ}^{2}$} \\
\hline & Mean & $\mathrm{SD}$ & Mean & $\mathrm{SD}$ \\
\hline \multicolumn{5}{|l|}{ Fresh samples ${ }^{3}$} \\
\hline DM, \% & 37.6 & 0.54 & 39.1 & 0.47 \\
\hline $\mathrm{NDF}, \%$ of DM & 50.4 & 0.54 & 52.6 & 0.46 \\
\hline $\mathrm{ADF}, \%$ of $\mathrm{DM}$ & 26.1 & 1.10 & 21.8 & 1.00 \\
\hline $\mathrm{CP}, \%$ of $\mathrm{DM}$ & 8.6 & 0.14 & 12.4 & 0.12 \\
\hline Starch, \% of DM & 26.3 & 0.17 & 24.6 & 0.14 \\
\hline $30-\mathrm{h}$ in vitro NDF digestibility, $\%$ of NDF & 51.7 & 0.65 & 60.5 & 0.57 \\
\hline \multicolumn{5}{|l|}{ Silage samples ${ }^{4}$} \\
\hline $\mathrm{DM}, \%$ & 38.0 & 0.35 & 38.5 & 0.35 \\
\hline $\mathrm{NDF}, \%$ of $\mathrm{DM}$ & 43.7 & 0.38 & 38.0 & 0.38 \\
\hline $\mathrm{ADF}, \%$ of $\mathrm{DM}$ & 26.1 & 1.52 & 23.4 & 1.52 \\
\hline $\mathrm{CP}, \%$ of $\mathrm{DM}$ & 8.6 & 0.21 & 13.5 & 0.21 \\
\hline Starch, \% of DM & 25.3 & 0.15 & 25.2 & 0.15 \\
\hline $30-\mathrm{h}$ in vitro NDF digestibility, $\%$ of NDF & 45.5 & 1.47 & 50.3 & 1.47 \\
\hline \multicolumn{5}{|l|}{ Particle size, ${ }^{5} \%$ of DM } \\
\hline Top (>19 mm) & 9.6 & 2.53 & 13.3 & 2.53 \\
\hline Middle ( 8 to $19 \mathrm{~mm}$ ) & 55.8 & 2.98 & 52.2 & 2.98 \\
\hline Bottom $(<8 \mathrm{~mm})$ & 34.7 & 0.75 & 34.6 & 0.75 \\
\hline
\end{tabular}

${ }^{1} \mathrm{BM}=$ barley planted on May 5.

${ }^{2} \mathrm{BJ}=$ barley planted on June 7 .

${ }^{3}$ Samples were taken from each load at harvest ( $n=4$ for BJ and $n=3$ for BM).

${ }^{4}$ Samples were taken from period 1 and 2 of the animal study ( $\mathrm{n}=2$ for each treatment; silage samples were collected daily during the collection period and composited for each period).

${ }^{5}$ Determined with Penn State Particle Separator (Nasco, Fort Atkinson, WI) for samples collected during the animal study (Lammers et al., 1996). 
Table 3. Ingredients and nutrient composition of experimental diets (\% of dietary DM)

\begin{tabular}{lcc}
\hline & \multicolumn{2}{c}{ Treatment $^{1}$} \\
\cline { 2 - 3 } Item & BM & BJ \\
\hline Ingredients, \% of DM & & \\
Vivar barley silage planted in May & 58.5 & - \\
Vivar barley silage planted in June & - & 58.5 \\
Dry-rolled barley grain & 25.0 & 25.0 \\
Corn gluten meal & 10.0 & 9.3 \\
Canola meal & 4.1 & - \\
Urea & 0.2 & - \\
Beet pulp & - & 5.0 \\
Minerals and vitamins & \\
Nutrient composition & 2.3 & 2.3 \\
DM, \% & 47.2 & 49.1 \\
Forage NDF, \% of DM & 23.0 & 20.9 \\
NDF, \% of DM & 30.6 & 28.8 \\
CP, \% of DM & 19.7 & 20.0 \\
Starch, \% of DM & 28.1 & 28.2 \\
Ether extract, \% of DM & 1.8 & 1.9 \\
Forage:concentrate ratio & $59: 41$ & $59: 41$ \\
\hline
\end{tabular}

${ }^{1} \mathrm{BM}=$ barley silage planted on May 5 ; BJ = barley silage planted on June 7.

${ }^{2}$ Premix of minerals and vitamins contained $56 \%$ trace minerals and vitamins $(11.5 \% \mathrm{Na}, 17.8 \% \mathrm{Cl}, 0.7 \% \mathrm{~K}, 0.1 \% \mathrm{Ca}, 0.6 \% \mathrm{P}, 0.3 \%$ $\mathrm{Mg}, 0.23 \% \mathrm{~S}, 25 \mathrm{mg} / \mathrm{kg}$ of Se, $6.2 \mathrm{mg} / \mathrm{kg}$ of Co, $80 \mathrm{mg} / \mathrm{kg}$ of I, 1,170 $\mathrm{mg} / \mathrm{kg}$ of $\mathrm{Cu}, 3,100 \mathrm{mg} / \mathrm{kg}$ of $\mathrm{Mn}, 5,000 \mathrm{mg} / \mathrm{kg}$ of $\mathrm{Zn}, 1,265 \mathrm{KIU} / \mathrm{kg}$ of vitamin $\mathrm{A}, 142 \mathrm{KIU} / \mathrm{kg}$ of vitamin $\mathrm{D}$, and $3,800 \mathrm{IU} / \mathrm{kg}$ of vitamin $\mathrm{E}$ ), $22 \%$ limestone, $11 \%$ dicalcium phosphate, and $11 \%$ magnesium oxide (DM basis).

diately before drying in a forced-air oven at $55^{\circ} \mathrm{C}$. Blood was collected from the coccygeal vessels using Vacutainer tubes containing sodium heparin (Becton Dickinson, Franklin Lakes, NJ). Blood samples were immediately placed on ice and centrifuged within $1 \mathrm{~h}$ at $4^{\circ} \mathrm{C}$ for $30 \mathrm{~min}$ at $3,000 \times \mathrm{g}$. Plasma was collected and stored at $-20^{\circ} \mathrm{C}$ for further analysis.

Rumen fluid samples were collected from 6 ruminally cannulated cows every $2 \mathrm{~h}$, starting at $0900 \mathrm{~h}$ on $\mathrm{d} 17$ and continued for $24 \mathrm{~h}(\mathrm{n}=12$ per period), to determine rumen $\mathrm{pH}$ and concentrations of VFA and $\mathrm{NH}_{3}$. Samples $(100 \mathrm{~g})$ were taken from 5 to 6 different sites in the rumen, strained through cheesecloth, and frozen at $-20^{\circ} \mathrm{C}$ for further analysis. Contents from the rumen were evacuated manually through the rumen fistula at $1400 \mathrm{~h}$ ( $3 \mathrm{~h}$ after feeding) on $\mathrm{d} 18$ and at $0800 \mathrm{~h}(3 \mathrm{~h}$ before feeding) on d 19 of each period. During evacuation of ruminal contents, a $10 \%$ aliquot of digesta was separated for the ease of subsampling. This aliquot was squeezed through cheesecloth to separate the sample into primarily solid and liquid phases. Samples were taken from both phases to obtain representative samples accounting for proportions of liquid and solid phases more accurately. These samples were analyzed for nutrient composition to calculate ruminal pool size of nutrients and ruminal turnover rates.
Diet ingredients, orts, feces, and solid ruminal digesta collected during the animal study were dried in a $55^{\circ} \mathrm{C}$ forced-air oven for $72 \mathrm{~h}$ and analyzed for DM concentration. Liquid ruminal digesta samples were freeze-dried because they would not be completely dried in a $55^{\circ} \mathrm{C}$ forced-air oven. Dried samples were ground through a $1-\mathrm{mm}$ screen with a Wiley mill (ThomasWiley, Philadelphia, PA). The DM concentration was determined by drying samples at $135^{\circ} \mathrm{C}$ for $2 \mathrm{~h}$ (AOAC, 2002; method 930.15). Ash concentration was determined after $5 \mathrm{~h}$ in a $550^{\circ} \mathrm{C}$ furnace (AOAC, 2002; method 942.05). The CP concentration was determined by flash combustion with gas chromatography and thermal conductivity detection (AOAC, 2000; method 990.03). The NDF concentration was determined using sodium sulfite and amylase (Van Soest et al., 1991). Indigestible NDF was estimated as NDF residue after $120 \mathrm{~h}$ in the rumen (Cochran et al., 1986). Samples measured for starch were gelatinized with sodium hydroxide and then measured with an enzymatic method (Karkalas, 1985), and glucose concentration was measured using a glucose oxidase-peroxidise enzyme (No. P7119, Sigma, St. Louis, MO) and dianisidine dihydrochloride (No. F5803, Sigma). A plate reader (SpectraMax 190, Molecular Devices Corp., Sunnyvale, CA) was used to determine absorbance. Ether extract concentration was determined using a Goldfisch extraction apparatus (Labconco, Kansas City, MO; AOAC, 1980). Particle size distribution for the TMR and orts samples was determined using a Penn State Particle Separator (19.0- and 8.0-mm sieves; Nasco, Fort Atkinson, WI; Lammers et al., 1996).

Milk samples were analyzed for fat, $\mathrm{CP}$, and lactose concentrations and SCC with infrared spectroscopy by Edmonton-Alberta DHIA (MilkOScan 605, Foss Electric, Hillerød, Denmark; AOAC, 1996). The MUN was determined with an automated infrared Fossomatic 400 milk analyzer (Foss North America, Brampton, Ontario, Canada). Milk fatty acids were extracted, and after esterification, fatty acid profiles were determined using gas chromatography (Khorasani et al., 1991). Plasma insulin concentrations were determined using a commercial kit (Coat-A-Count, Diagnostic Products Corporation, Los Angeles, CA). Plasma glucose concentration was determined using a glucose oxidase-peroxidise enzyme and dianisidine dihydrochloride as described above.

Rumen fluid samples were centrifuged at $26,000 \times g$ for $15 \mathrm{~min}$, and supernatants were collected. The centrifuged supernatant was analyzed for VFA by gas chromatography (Khorasani et al., 1996), and $\mathrm{NH}_{3}$ concentration was also determined (Fawcett and Scott, 1960). Ruminal pool size (kg) of DM, NDF, indigestible NDF, $\mathrm{OM}$, and starch were determined by multiplying the 
Table 4. Average daily mean temperature and precipitation during the 2005 growing season and effects of planting date on nutrient composition of fresh whole-crop barley

\begin{tabular}{|c|c|c|c|c|}
\hline \multirow[b]{2}{*}{ Item } & \multicolumn{2}{|c|}{ Treatment $^{1}$} & \multirow[b]{2}{*}{$\mathrm{SE}$} & \multirow[b]{2}{*}{$P$-value } \\
\hline & $\mathrm{BM}$ & BJ & & \\
\hline \multicolumn{5}{|l|}{ Planting to heading } \\
\hline Days & 62 & 50 & - & - \\
\hline Average daily mean temperature, ${ }^{\circ} \mathrm{C}$ & 13.3 & 15.1 & - & - \\
\hline Average precipitation, mm/d & 1.6 & 2.3 & - & - \\
\hline \multicolumn{5}{|l|}{ Heading to harvest } \\
\hline Days & 21 & 30 & - & - \\
\hline Average daily mean temperature, ${ }^{\circ} \mathrm{C}$ & 15.9 & 14.3 & - & - \\
\hline Average precipitation, $\mathrm{mm} / \mathrm{d}$ & 2.5 & 3.4 & - & - \\
\hline \multicolumn{5}{|l|}{ Planting to harvest } \\
\hline Days & 83 & 80 & - & - \\
\hline Average daily mean temperature, ${ }^{\circ} \mathrm{C}$ & 14.0 & 14.8 & - & - \\
\hline Average precipitation, $\mathrm{mm} / \mathrm{d}$ & 1.9 & 2.7 & - & - \\
\hline $\mathrm{NDF}, \%$ of $\mathrm{DM}$ & 51.3 & 52.5 & 0.66 & 0.34 \\
\hline $30-\mathrm{h}$ in vitro NDF digestibility, $\%$ of NDF & 51.9 & 61.2 & 0.52 & $<0.01$ \\
\hline $\mathrm{CP}, \%$ of $\mathrm{DM}$ & 8.7 & 12.4 & 0.08 & $<0.01$ \\
\hline Starch, \% of DM & 25.9 & 23.0 & 1.11 & 0.21 \\
\hline
\end{tabular}

${ }^{1} \mathrm{BM}=$ fresh whole-crop barley planted on May 5; BJ = fresh whole-crop barley planted on June 7.

concentration of each component by the ruminal digesta DM weight (kg) except for DM. Rumen turnover rate was calculated for each component by the equation below:

turnover rate in the rumen $(\% / \mathrm{h})=$

(intake of component/ruminal

pool of component)/24 $\times 100$.

For the animal study, data were analyzed using the fit model procedure of JMP according to the model below:

$$
\mathrm{Y}_{\mathrm{ijkl}}=\mu+\mathrm{P}_{\mathrm{i}}+\mathrm{C}(\mathrm{P})_{\mathrm{j}(\mathrm{i})}+\mathrm{E}_{\mathrm{k}}+\mathrm{T}_{1}+\mathrm{PT}_{\mathrm{il}}+\mathrm{e}_{\mathrm{ijkl}},
$$

where $\mu$ overall mean; $\mathrm{P}_{\mathrm{i}}=$ fixed effect of parity $(\mathrm{i}=$ 1 to 2 ; primiparous vs. multiparous $) ; \mathrm{C}(\mathrm{P})_{\mathrm{j}(\mathrm{i})}=$ random effect of cows nested in parity $(j=1$ to 30$) ; E_{k}=$ fixed effect of period ( $\mathrm{k}=1$ to 2 ); $\mathrm{T}_{1}$ = fixed effect of treatment ( $1=1$ to 2$) ; \mathrm{PT}_{\mathrm{il}}=$ effect of interaction between parity and treatment; and $\mathrm{e}_{\mathrm{ijkl}}=$ residual, assumed to be normally distributed.

Treatment effect was declared significant at $P<0.05$, and its tendency was declared at $P<0.10$.

\section{RESULTS}

The BJ took $12 \mathrm{~d}$ less time to reach the heading stage from planting than BM (50 vs. $62 \mathrm{~d}$; Table 4). Average daily mean temperature and average precipitation over the period from planting to heading were greater for BJ compared with $\mathrm{BM}\left(15.1\right.$ vs. $13.3^{\circ} \mathrm{C}$ and 2.3 vs. 1.6 $\mathrm{mm} / \mathrm{d}$ ). However, BJ took $9 \mathrm{~d}$ longer from heading to reach the late-dough stage for harvest (30 vs. $21 \mathrm{~d}$ ). From heading to harvest, average daily mean temperature was lower for BJ ( 14.3 vs. $\left.15.9^{\circ} \mathrm{C}\right)$, and average precipitation was greater for BJ (3.4 vs. $2.5 \mathrm{~mm} / \mathrm{d}$ ). The BJ had greater IVFD than BM for samples collected closest to heading (72.4 vs. 57.5\%; Figure 1) and had no reduction of IVFD for the last 2 sampling dates. Harvested BJ samples had greater IVFD $(P<0.01)$ and $\mathrm{CP}(P<0.01)$ compared with BM.

The DMI was not affected by treatment and averaged $20.2 \mathrm{~kg} / \mathrm{d}$ (Table 5). However, intake of OM, NDF, and indigestible NDF were significantly greater for cows fed the BM diet $(P=0.03, P<0.01$, and $P<0.01)$. Milk yield was not affected by treatment and averaged 27.2 $\mathrm{kg} / \mathrm{d}$. Treatment did not affect milk fat, CP, or lactose concentrations. Somatic cell counts were significantly greater for cows fed BJ, but the count was below 200,000 cells $/ \mathrm{mL}$ for both treatments ( 195 vs. $153 \times 10^{3} / \mathrm{mL} ; P=$ $0.03)$. Milk fatty acid composition was affected by diet (Table 6). Concentrations of C13:0, C15:0, C17:0, and C19:0 were greater $(P=0.01, P=0.01, P<0.01$, and $P=0.04$, respectively) for cows fed BJ. However, concentrations of $\mathrm{C} 6: 0$ were greater $(P=0.03)$ for cows fed BM. Although some individual fatty acids were significantly different between treatments, the total short- and midchain fatty acid concentration $\left(\mathrm{C}_{4: 0}\right.$ to $\left.\mathrm{C}_{14}\right)$ was not different.

Cows fed the BJ diet had a tendency for an increase in BW $(P=0.06)$. For BCS, there was a significant interaction between parity and treatment $(P=0.04)$. Primiparous cows were not affected by treatment, but multiparous cows had greater BCS when they were fed the BJ diet $(P=0.04)$. There was no significant increase 


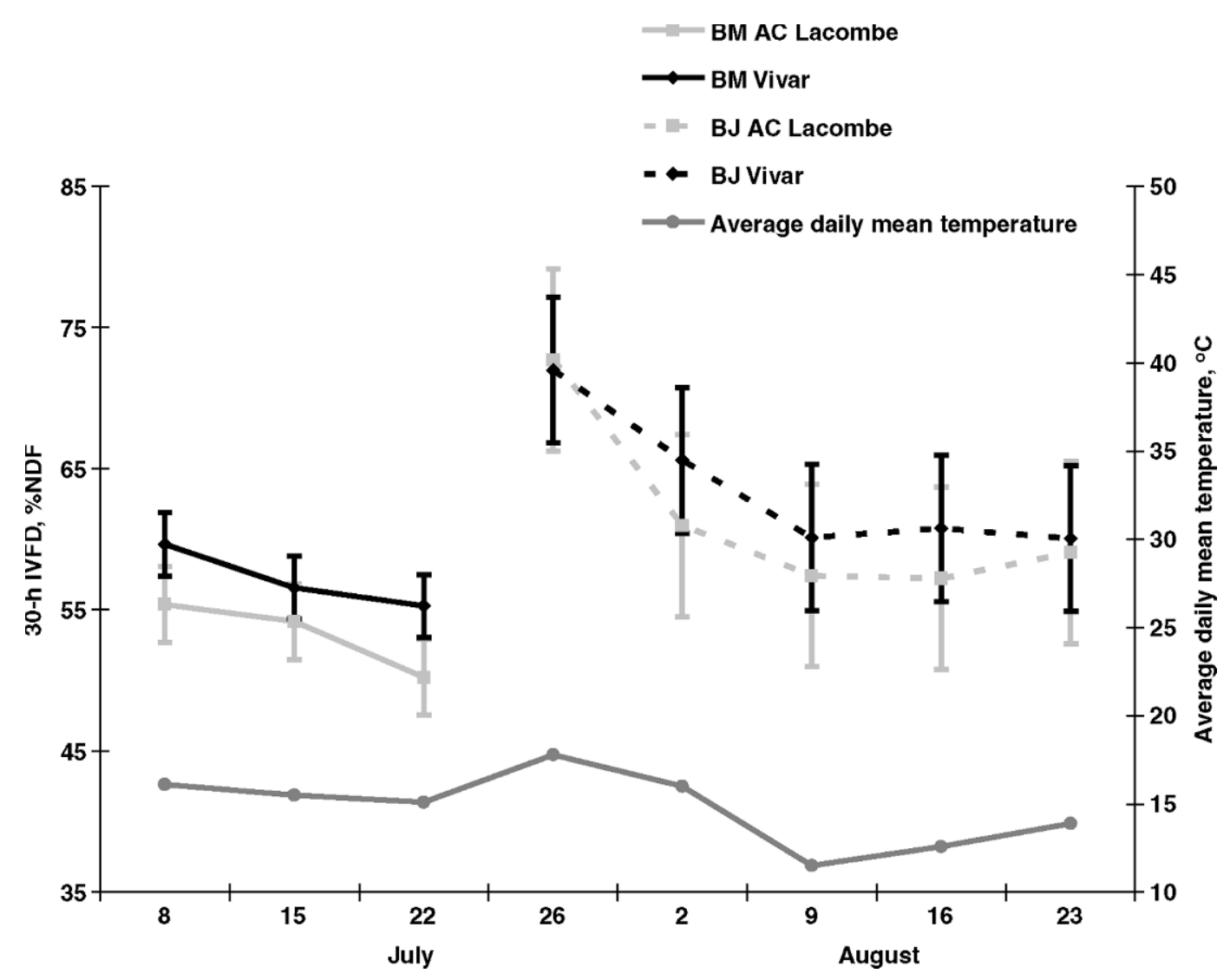

Figure 1. Daily mean temperature, averaged weekly, and changes in 30-h in vitro NDF digestibility (\%NDF; IVFD) from heading to harvest for AC Lacombe and Vivar whole-crop barley planted on either May 5 or June 7, 2005; BM = barley planted on May 5; BJ = barley planted on June 7.

in plasma glucose or insulin for cows fed BJ compared with those fed BM.

Ruminally cannulated cows fed the BM diet had significantly greater NDF and indigestible NDF intakes ( $P=0.01$ and $P<0.01$; Table 7$)$. Cows fed the BM diet also had significantly greater ruminal pool size for DM $(P=0.05)$ and a tendency for a greater NDF pool size $(P=0.06)$. However, the turnover rates of NDF and indigestible NDF were not affected by treatment. The turnover rate of DM tended to be greater for cows fed BJ than those fed $\mathrm{BM}(P=0.08)$. Ammonia concentration in rumen fluid was not affected by the source of silage (Table 8). The ruminal $\mathrm{pH}$ was also not different between BM and BJ diets. There were no significant treatment effects on total VFA concentration or composition of VFA.

Total tract nutrient digestibility was significantly greater for cows fed the BJ diet compared with those fed the BM diet for DM, OM, and CP $(P<0.01, P<$ 0.01 , and $P=0.01$, respectively; Table 9 ) but was lower for starch $(P=0.02)$. The NDF digestibility for BJ tended to be greater than $\mathrm{BM}(P=0.10)$.

\section{DISCUSSION}

\section{Effects of Planting Date on IVFD}

Barley planted on May 5 was harvested on July 26, and barley planted on June 7 was harvested on August 25 . To harvest at the same physiological maturity (late dough), the growing season of barley was staggered by 1 mo. Daily mean temperature averaged over each growing period was greater for BJ compared with BM in 2005, which is consistent with the past 20-yr record. Due to the higher temperature, it was expected that BJ would have lower IVFD, because as temperature increases, lignin synthesis is increased and IVFD is decreased (Fahey and Hussein, 1999), but we found that BJ had greater IVFD than BM. Average daily mean temperature was greater for BJ from planting to heading, but that from heading to harvest was lower for BJ than BM in 2005. Greater IVFD of BJ could have been due to the average daily mean temperature from heading to harvest having a more dominant effect on IVFD than that from planting to harvest. 
Table 5. Effects of BM and BJ silage on DMI, milk production, BW, $\mathrm{BCS}$, and plasma metabolites

\begin{tabular}{|c|c|c|c|c|}
\hline \multirow[b]{2}{*}{ Item } & \multicolumn{2}{|c|}{ Treatment $^{1}$} & \multirow[b]{2}{*}{$\mathrm{SE}$} & \multirow[b]{2}{*}{$P$-value } \\
\hline & BM & BJ & & \\
\hline \multicolumn{5}{|l|}{ Intake, kg/d } \\
\hline $\mathrm{DM}$ & 20.4 & 19.9 & 0.55 & 0.17 \\
\hline $\mathrm{OM}$ & 17.0 & 16.3 & 0.46 & 0.03 \\
\hline $\mathrm{CP}$ & 3.8 & 3.7 & 0.10 & 0.19 \\
\hline Starch & 5.5 & 5.3 & 0.14 & 0.06 \\
\hline NDF & 5.9 & 5.3 & 0.15 & $<0.01$ \\
\hline Indigestible NDF & 1.8 & 1.3 & 0.04 & $<0.01$ \\
\hline Ether extract & 0.3 & 0.4 & 0.01 & 0.43 \\
\hline \multicolumn{5}{|l|}{ Yield, kg/d } \\
\hline Milk & 27.2 & 27.1 & 1.11 & 0.84 \\
\hline $4 \% \mathrm{FCM}^{2}$ & 26.1 & 25.7 & 0.99 & 0.46 \\
\hline Milk fat & 1.01 & 0.99 & 0.04 & 0.41 \\
\hline Milk CP & 0.93 & 0.93 & 0.03 & 0.95 \\
\hline Milk lactose & 1.26 & 1.26 & 0.06 & 0.92 \\
\hline \multicolumn{5}{|l|}{ Milk composition } \\
\hline Fat, $\%$ & 3.77 & 3.72 & 0.11 & 0.50 \\
\hline $\mathrm{CP}, \%$ & 3.45 & 3.48 & 0.06 & 0.19 \\
\hline Lactose, \% & 4.58 & 4.60 & 0.04 & 0.65 \\
\hline MUN, mg/dL & 12.0 & 11.6 & 0.29 & 0.19 \\
\hline SCC, $\times 10^{3} / \mathrm{mL}$ & 153 & 195 & 35.0 & 0.03 \\
\hline BW change, g/d & 504 & 864 & 129 & 0.06 \\
\hline \multicolumn{5}{|l|}{ BCS change, /19 d } \\
\hline Parity $\times$ treatment interaction & & & & 0.04 \\
\hline Primiparous cows & 0.00 & -0.05 & 0.04 & 0.41 \\
\hline Multiparous cows & -0.02 & 0.13 & 0.05 & 0.04 \\
\hline Plasma glucose, mg/dL & 56.2 & 57.1 & 0.70 & 0.37 \\
\hline Plasma insulin, $\mu \mathrm{IU} / \mathrm{mL}$ & 11.4 & 11.7 & 0.74 & 0.81 \\
\hline
\end{tabular}

${ }^{1} \mathrm{BM}=$ barley silage planted on May 5 ; BJ = barley silage planted on June 7.

${ }^{2} 4 \% \mathrm{FCM}=(0.4 \times$ milk yield, $\mathrm{kg})+(15 \times$ milk fat yield, $\mathrm{kg})$.

The second half of the growing season (July and August) can be separated into 3 periods that differ in daily mean temperature (July 8 to 22, intermediate; July 26 to August 2, high; August 9 to 23, low; Figure 1). During the first 2 wk after heading, BJ was exposed to the highest daily mean temperatures and had a $13.6 \%$ unit reduction in IVFD during this 2 -wk period. However, BJ was exposed to the lowest daily mean temperatures from $2 \mathrm{wk}$ after heading to harvest and had little or no reduction in IVFD during this period. Contrarily, BM was exposed to temperatures intermediate to the aforementioned 2 periods from heading to harvest and had a 4.7-unit decrease in IVFD. The relationship between daily mean temperature and reductions in IVFD suggests that higher ambient temperature causes greater cell wall lignification and decrease in IVFD. The enhanced IVFD observed for BJ compared with BM in this study might be attributed to the lower average daily mean temperature from heading to harvest for BJ compared with BM at Edmonton in 2005. However, this effect may not be consistently seen every year, because the average daily mean temperatures during the corresponding periods for the past $20 \mathrm{yr}$ were not
Table 6. Effects of BM and BJ silage on composition of milk fatty acids

\begin{tabular}{|c|c|c|c|c|}
\hline \multirow[b]{2}{*}{ Item } & \multicolumn{2}{|c|}{ Treatment $^{1}$} & \multirow[b]{2}{*}{$\mathrm{SE}$} & \multirow[b]{2}{*}{$P$-value } \\
\hline & $\mathrm{BM}$ & BJ & & \\
\hline $\mathrm{C}_{4: 0}$ & 1.37 & 1.34 & 0.03 & 0.46 \\
\hline $\mathrm{C}_{6: 0}$ & 1.99 & 1.92 & 0.03 & 0.03 \\
\hline $\mathrm{C}_{8: 0}$ & 1.51 & 1.48 & 0.03 & 0.39 \\
\hline $\mathrm{C}_{10: 0}$ & 3.91 & 3.91 & 0.11 & 0.99 \\
\hline $\mathrm{C}_{11: 0}$ & 0.18 & 0.21 & 0.02 & 0.06 \\
\hline $\mathrm{C}_{12: 0}$ & 4.88 & 5.00 & 0.15 & 0.30 \\
\hline $\mathrm{C}_{13: 0}$ & 0.23 & 0.27 & 0.02 & 0.01 \\
\hline $\mathrm{C}_{14: 0}$ & 13.4 & 13.3 & 0.23 & 0.75 \\
\hline $\mathrm{C}_{14: 1}$ & 1.48 & 1.58 & 0.05 & 0.06 \\
\hline $\mathrm{C}_{15: 0}$ & 1.70 & 1.95 & 0.10 & 0.01 \\
\hline $\mathrm{C}_{16: 0}$ & 34.6 & 34.6 & 0.56 & 0.87 \\
\hline $\mathrm{C}_{16: 1}$ & 2.21 & 2.27 & 0.08 & 0.33 \\
\hline $\mathrm{C}_{17: 0}$ & 0.66 & 0.71 & 0.02 & $<0.01$ \\
\hline $\mathrm{C}_{17: 1}$ & 0.38 & 0.39 & 0.02 & 0.81 \\
\hline $\mathrm{C}_{18: 0}$ & 7.73 & 7.44 & 0.18 & 0.09 \\
\hline $\mathrm{C}_{18: 1}$ trans & 1.79 & 2.06 & 0.15 & 0.10 \\
\hline $\mathrm{C}_{18: 1}$ cis -9 & 19.0 & 18.6 & 0.62 & 0.22 \\
\hline $\mathrm{C}_{18: 2}$ & 2.69 & 2.58 & 0.14 & 0.54 \\
\hline $\mathrm{C}_{18: 3} \mathrm{n}-6$ & 0.10 & 0.09 & 0.02 & 0.85 \\
\hline $\mathrm{C}_{18: 3} \mathrm{n}-3$ & 0.14 & 0.16 & 0.03 & 0.70 \\
\hline $\mathrm{C}_{19: 0}$ & 0.09 & 0.16 & 0.02 & 0.04 \\
\hline $\begin{array}{l}\text { Short and mid-chain } \\
\text { fatty acids }\left(\mathrm{C}_{4: 0} \text { to } \mathrm{C}_{14}\right)\end{array}$ & 28.9 & 29.0 & 0.52 & 0.79 \\
\hline
\end{tabular}

distinctively different: $17.4 \pm 1.04$ vs. $16.6 \pm 1.67^{\circ} \mathrm{C}$ (mean \pm SD) for BM and BJ, respectively.

For the Vivar fresh whole-crop barley, BJ had an 8.8unit greater IVFD than BM (60.5 vs. $51.7 \%)$. However, it is noteworthy that BJ and BM had 10.2- and 6.2unit reductions in IVFD during the ensiling process, respectively. Thus, the difference in silage IVFD was reduced to 4.8 units between $\mathrm{BJ}$ and $\mathrm{BM}$ (50.3 vs. 45.5\%). The decrease in IVFD was likely caused by the reduction of the more degradable cell wall fraction; ensiled samples decreased in NDF compared with fresh samples, but there was little change in $\mathrm{ADF}, \mathrm{CP}$, and starch concentrations. Because ADF primarily consists of lignin and cellulose whereas NDF consists of lignin, cellulose, and hemicellulose, the decrease in silage IVFD suggests that hemicelluose disappeared likely by acid hydrolysis. Similarly, Dado and Allen (1996) found that ensiling alfalfa decreased NDF content and NDF digestibility (average of 1.4 and $2.9 \%$ unit decrease for NDF and 24-h IVFD, respectively, for 2 alfalfa silages) and that the extent of reductions in NDF and IVFD was greater for the alfalfa with enhanced IVFD before ensiling.

\section{DMI and Milk Production}

It was expected that feeding BJ would increase DMI and milk production due to its greater IVFD and lower 
Table 7. Effects of BM and BJ silage on intake, nutrient mass in rumen, and ruminal turnover rate on ruminally cannulated cows

\begin{tabular}{|c|c|c|c|c|}
\hline \multirow[b]{2}{*}{ Item } & \multicolumn{2}{|c|}{ Treatment $^{1}$} & \multirow[b]{2}{*}{$\mathrm{SE}$} & \multirow[b]{2}{*}{$P$-value } \\
\hline & $\mathrm{BM}$ & BJ & & \\
\hline \multicolumn{5}{|l|}{ Intake, ${ }^{2} \mathrm{~kg} / \mathrm{d}$} \\
\hline $\mathrm{DM}$ & 19.7 & 19.7 & 0.61 & 0.84 \\
\hline $\mathrm{OM}$ & 17.4 & 17.2 & 0.54 & 0.59 \\
\hline $\mathrm{NDF}$ & 6.0 & 5.7 & 0.07 & 0.01 \\
\hline Indigestible NDF & 1.8 & 1.4 & 0.05 & $<0.01$ \\
\hline Starch & 5.6 & 5.6 & 0.18 & 0.66 \\
\hline \multicolumn{5}{|c|}{ Nutrient mass in the rumen, $\mathrm{kg}$} \\
\hline Wet digesta & 81.5 & 76.0 & 2.51 & 0.16 \\
\hline $\mathrm{DM}$ & 16.7 & 14.8 & 0.58 & 0.05 \\
\hline $\mathrm{OM}$ & 13.8 & 12.5 & 0.50 & 0.10 \\
\hline NDF & 8.7 & 7.8 & 0.36 & 0.06 \\
\hline Indigestible NDF & 4.5 & 3.5 & 0.39 & 0.13 \\
\hline Starch & 0.8 & 0.7 & 0.11 & 0.75 \\
\hline \multicolumn{5}{|c|}{ Ruminal turnover rate, $\% / \mathrm{h}$} \\
\hline DM & 4.95 & 5.60 & 0.24 & 0.08 \\
\hline $\mathrm{OM}$ & 5.28 & 5.80 & 0.26 & 0.16 \\
\hline NDF & 2.89 & 3.10 & 0.17 & 0.34 \\
\hline Indigestible NDF & 1.84 & 1.85 & 0.25 & 0.99 \\
\hline Starch & 30.2 & 32.3 & 4.29 & 0.77 \\
\hline
\end{tabular}

${ }^{1} \mathrm{BM}=$ barley silage planted on May 5 ; BJ = barley silage planted on June 7.

${ }^{2}$ Measurements taken from ruminally cannulated cows $(\mathrm{n}=6)$.

NDF content compared with BM. However, treatment did not affect DMI or milk yield. In this experiment, diets had originally been formulated, based on data from the fresh whole-crop barley, to supply a high dietary NDF content of approximately 37 and $39 \%$ of dietary DM for BM and BJ diets, respectively. Although cows used in the study were at a late stage of lactation $(183 \pm 71.7$ DIM; mean \pm SD), experimental diets that are high in dietary forage NDF were expected to limit DMI by ruminal distension and physical fill (Johnson and Combs, 1991; Dado and Allen, 1995). However, diets actually fed to cows during the study contained

Table 8. Effects of BM and BJ silage on ruminal $\mathrm{pH}$ and rumen fermentation on ruminally cannulated cows ${ }^{1}$

\begin{tabular}{|c|c|c|c|c|}
\hline \multirow[b]{2}{*}{ Item } & \multicolumn{2}{|c|}{ Treatment $^{2}$} & \multirow[b]{2}{*}{$\mathrm{SE}$} & \multirow[b]{2}{*}{$P$-value } \\
\hline & $\mathrm{BM}$ & BJ & & \\
\hline Ruminal pH & 6.07 & 5.97 & 0.04 & 0.16 \\
\hline $\mathrm{NH}_{3}, \mathrm{~m} M$ & 9.3 & 11.3 & 0.87 & 0.19 \\
\hline Total VFA, mM & 144 & 151 & 5.01 & 0.43 \\
\hline \multicolumn{5}{|l|}{ VFA, mol/100 mol of VFA } \\
\hline Acetic acid & 58.5 & 56.5 & 1.25 & 0.17 \\
\hline Propionic acid & 20.1 & 20.6 & 1.54 & 0.78 \\
\hline Butyric acid & 13.1 & 14.1 & 0.66 & 0.33 \\
\hline Branched-chain $\mathrm{VFA}^{3}$ & 2.3 & 2.4 & 0.13 & 0.48 \\
\hline Acetic:propionate ratio & $3.0: 1$ & $2.8: 1$ & 0.23 & 0.34 \\
\hline
\end{tabular}

\footnotetext{
${ }^{1}$ Measurements taken from ruminally cannulated cows $(\mathrm{n}=6)$.

${ }^{2} \mathrm{BM}=$ barley silage planted on May 5 ; BJ = barley silage planted on June 7.

${ }^{3}$ Branched-chain VFA: isobutyric and isovaleric.
}

Table 9. Effects of BM and BJ silage on total tract nutrient digestibility $(\%)$

\begin{tabular}{llllr}
\hline & \multicolumn{2}{c}{ Treatment $^{1}$} & & \\
\cline { 2 - 3 } Item & BM & BJ & SE & $P$-value \\
\hline DM, \% & 66.1 & 68.9 & 0.56 & $<0.01$ \\
OM, \% & 69.0 & 70.9 & 0.52 & $<0.01$ \\
CP, \% & 69.8 & 72.0 & 0.79 & 0.01 \\
NDF, \% & 42.1 & 44.1 & 1.06 & 0.10 \\
Starch, \% & 97.5 & 97.0 & 0.18 & 0.02 \\
Ether extract, \% & 65.7 & 63.6 & 1.78 & 0.27 \\
\hline
\end{tabular}

${ }^{1} \mathrm{BM}=$ barley silage planted on May 5 ; BJ = barley silage planted on June 7.

significantly lower dietary NDF than expected due to the drastic reduction in NDF during ensiling; dietary NDF concentrations were 30.6 and $28.8 \%$ for $\mathrm{BM}$ and BJ treatments, respectively. Therefore, DMI might not have been limited by physical fill for this study. This speculation was supported by the data of ruminal pool size and turnover rate of NDF. Cows fed the BM diet had significantly greater NDF and indigestible NDF intakes and also had significantly greater ruminal pool size for DM and a tendency for a greater NDF pool size. However, treatment did not affect turnover rates of NDF and indigestible NDF. If physical fill had limited maximum DMI of animals, a greater NDF intake would have been associated with a greater turnover rate of $\mathrm{NDF}$ and no change in rumen pool size of NDF, but these were not observed.

Milk yield was not affected in this study, which disagreed with the finding that milk yield is increased by enhanced IVFD of corn silage (Oba and Allen, 1999b; Ballard et al., 2001; Ivan et al., 2005), sorghum silage (Grant et al., 1995; Aydin et al., 1999), or alfalfa silage (Dado and Allen, 1996). However, Tine et al. (2001) did not see an increase in milk yield when cows were fed the more digestible brown midrib corn silage vs. normal corn silage, and this could be due to the low milk production for cows used in their study. Similarly, Weiss and Wyatt (2002) also evaluated 2 corn silage hybrids that differed in IVFD (35.4 vs. $40.1 \%$ ) using cows in late lactation (174 \pm 20 DIM) and found no treatment effects on milk yield. The positive effects of enhanced forage IVFD on milk yield may not be able to be observed unless milk production is limited by energy intake. Although the experimental periods were relatively short (i.e., $19 \mathrm{~d}$ ) for the present study, it is not expected that longer experimental periods would have resulted in different animal responses, because physical fill did not likely limit energy intake and milk production for animals used in this study. 


\section{Energy Utilization and Rumen Fermentation}

Total tract nutrient digestibility was greater for cows fed the BJ diet compared with those fed the BM for $\mathrm{DM}, \mathrm{OM}$, and $\mathrm{CP}$, and tended to be greater for NDF. The greater total tract digestibility of BJ may have provided additional energy, which might explain the tendency for an increase in BW for cows fed BJ. An interaction between parity and treatment was found for BCS gain; treatment did not affect BCS of primiparous cows, but multiparous cows fed BJ had greater BCS gain. The additional energy may have been deposited as fat for multiparous cows but may have been used for lean tissue gain for primiparous cows, because they did not change in BCS. According to the NRC (2001), cows reach a mature $\mathrm{BW}$ at the beginning of the third lactation, suggesting that primiparous cows still gain lean tissue mass. However, $\mathrm{N}$ excretion in urine was not determined in this study. Thus, it cannot be concluded that primiparous cows fed BJ retained more $\mathrm{N}$ than those fed BM.

Further, there were no effects of treatment on plasma glucose and insulin concentrations. It was expected that greater BCS gain for multiparous cows fed BJ would have been associated with an increase in plasma glucose and insulin concentrations (Rao et al., 1973). However, lack of responses in glucose or insulin suggest that we need to be cautious about the interpretation of BCS data. Treatment periods of $19 \mathrm{~d}$ may have been too short to evaluate treatment effects on BCS changes. There has been inconsistency in the literature regarding the effects of enhanced forage IVFD on BW and BCS changes. Some studies have found that forage IVFD has no significant effects on BW and BCS (Aydin et al., 1999; Oba and Allen, 1999b; Ballard et al., 2001). However, other studies reported that cows fed brown midrib 3 -corn silage, which is high in IVFD, partitioned extra energy to BW gain instead of increasing milk production (Sommerfeldt et al., 1979; Block et al., 1981).

There were no significant effects of treatment on ruminal $\mathrm{pH}$, which is in agreement with many previous studies evaluating forage IVFD (Grant et al., 1995; Aydin et al., 1999; Ivan et al., 2005). The VFA concentration and its profile were similar between the treatments in the present study. Furthermore, treatment did not affect the concentration of trans $\mathrm{C}_{18: 1}$ in milk. It has been reported that low rumen $\mathrm{pH}$ increases the absorption of trans $\mathrm{C}_{18: 1}$ and its appearance in milk fat by inhibiting its conversion to stearic acid (Kalscheur et al., 1997). Thus, these data suggested that rumen fermentation was not affected by treatment.

\section{CONCLUSIONS}

Delaying the planting date of barley changed its growing environment and affected nutrient composi- tion and IVFD of whole-crop barley. The BJ had greater IVFD compared with BM, but cows fed BJ did not increase DMI or milk production. The lack of positive responses could have been attributed to the lower milk production or late stage of lactation of cows used in this experiment; ruminal physical fill might not have limited their DMI. However, cows fed BJ increased nutrient digestibility, and the additional energy may have been partitioned to BW gain. Further research is needed to evaluate whether planting date of barley consistently affects nutrient composition and IVFD. Also, the effects of IVFD of barley silage on DMI and milk production need to be evaluated using high-producing cows, in which physical fill is more dominant in the regulation of feed intake.

\section{ACKNOWLEDGMENTS}

We wish to acknowledge Alberta Milk, Alberta Ingenuity Fund, and Natural Science Engineering Research Council of Canada for their financial support of this research project. We also thank C. Silveira, K. Lien, P. Regmi, B. Khaniya, M. A. Bal, C. Wiebe-Buchanan, L. Manson, and J. Bilobrowka at the University of Alberta, Edmonton, Canada, for their assistance in sample analysis. We also thank the staff at the Dairy Research and Technology Centre at the University of Alberta, Edmonton, Canada, for animal care.

\section{REFERENCES}

Allen, M. S. 1996. Physical constraints on voluntary intake of forages by ruminants. J. Anim. Sci. 74:3063-3075.

Allen, M. S. 1997. Relationship between fermentation acid production in the rumen and the requirement for physically effective fiber. J. Dairy Sci. 80:1447-1462.

AOAC. 1980. Official Methods of Analysis. 13th ed. Assoc. Off. Anal. Chem., Washington, DC.

AOAC. 1996. Official Methods of Analysis. 16th ed. Assoc. Off. Anal. Chem., Gaithersburg, M.D.

AOAC. 2000. Official Methods of Analysis. 17th ed. Assoc. Off. Anal. Chem., Arlington, VA.

AOAC. 2002. Official Methods of Analysis. 17th ed. Rev. 1. Assoc. Off. Anal. Chem., Arlington, VA.

Aydin, G., R. J. Grant, and J. O'Rear. 1999. Brown midrib sorghum in diets for lactating dairy cows. J. Dairy Sci. 82:2127-2135.

Ballard, C. S., E. D. Thomas, D. S. Tsang, P. Mandebvu, C. J. Sniffen, M. I. Endres, and M. P. Carter. 2001. Effect of corn silage hybrid on dry matter yield, nutrient composition, in vitro digestion, intake by dairy heifers, and milk production by dairy cows. J. Dairy Sci. 84:442-452.

Beauchemin, K. A., and L. M. Rode. 1997. Minimum vs. optimum concentrations of fiber in dairy cow diets based on barley silage and concentrates of barley or corn. J. Dairy Sci. 80:1629-1639.

Block, E., L. D. Muller, L. C. Griel Jr., and D. L. Garwood. 1981. Brown midrib-3 corn silage and heat extruded soybeans for early lactating dairy cows. J. Dairy Sci. 64:1813-1825.

Cochran, R. C., D. C. Adams, J. D. Wallace, and M. L. Galyean. 1986. Predicting digestibility of different diets with internal markers: Evaluation of four potential markers. J. Anim. Sci. 63:1476-1483.

Dado, R. G., and M. S. Allen. 1995. Intake limitations, feeding behavior, and rumen function of cows challenged with rumen fill from dietary fiber or inert bulk. J. Dairy Sci. 78:118-133. 
Dado, R. G., and M. S. Allen. 1996. Enhanced intake and production of cows offered ensiled alfalfa with higher neutral detergent fibre digestibility. J. Dairy Sci. 79:418-428.

Environmental Canada. 2006. Daily data report. http://www.climate.weatheroffice.ec.gc.ca/climateData/dailydata_e.html Accessed May 1, 2007.

Fahey, G. C. J., and H. S. Hussein. 1999. Forty years of forage quality research: Accomplishments and impact from an animal nutrition perspective. Crop Sci. 39:4-12.

Fawcett, J. K., and J. E. Scott. 1960. A rapid and precise method for the determination of urea. J. Clin. Pathol. 13:156-160.

Grant, R. J., S. G. Haddad, K. J. Moore, and J. F. Pedersen. 1995. Brown midrib sorghum silage for midlactation dairy cows. J. Dairy Sci. 78:1970-1980.

Grummer, R. R., P. C. Hoffman, M. L. Luck, and S. J. Bertics. 1995. Effect of prepartum and postpartum dietary energy on growth and lactation of primiparous cows. J. Dairy Sci. 78:172-180.

Holm, J, I. Bjorck, A. Drews, and N. G. Asp. 1986. A rapid method for the analysis of starch. Starch/Starke 38:224-226.

Ivan, S. K., R. J. Grant, D. Weakley, and J. Beck. 2005. Comparison of a corn silage hybrid with high cell-wall content and digestibility with a hybrid of lower cell-wall content on performance of Holstein cows. J. Dairy Sci. 88:244-254.

Johnson, T. R., and D. K. Combs. 1991. Effects of prepartum diet, inert rumen bulk, and dietary polyethylene glycol on dry matter intake of lactating dairy cows. J. Dairy Sci. 74:933-944.

Kalscheur, K. F., B. B. Teter, L. S. Piperova, and R. A. Erdman. 1997. Effect of dietary forage concentration and buffer addition on duodenal flow of trans-C18:1 fatty acids and milk fat production in dairy cows. J. Dairy Sci. 80:2104-2114.

Karkalas, J. 1985. An improved enzymatic method for the determination of native and modified starch. J. Sci. Food Agric. 36:10191027.

Khorasani, G. R., E. K. Okine, and J. J. Kennelly. 1996. Forage source alters nutrient supply to the intestine without influencing milk yield. J. Dairy Sci. 79:862-872.

Khorasani, G. R., P. H. Robinson, G. De Boer, and J. J. Kennelly. 1991. Influence of canola fat on yield, fat percentage, fatty acid profile, and nitrogen fractions in Holstein milk. J. Dairy Sci. 74:1904-1911.

Lammers, B. P., D. R. Buckmaster, and A. J. Heinrichs. 1996. A simple method for the analysis of particle sizes of forage and total mixed rations. J. Dairy Sci. 79:922-928.
Llamas-Lamas, G., and D. K. Combs. 1990. Effect of alfalfa maturity on fiber utilization by high producing dairy cows. J. Dairy Sci. 73:1069-1080.

Mertens, D. R. 1987. Predicting intake and digestibility using mathematical models of ruminal function. J. Anim. Sci. 64:1548-1558.

Nocek, J. E., and J. B. Russell. 1988. Protein and energy as an integrated system. Relationship of ruminal protein and carbohydrate availability to microbial synthesis and milk production. J. Dairy Sci. 71:2070-2107.

NRC. 2001. Nutrient Requirements of Dairy Cattle. 7th ed. Natl. Acad. Press, Washington, DC.

Oba, M., and M. S. Allen. 1999a. Evaluation of the importance of the digestibility of neutral detergent fiber from forage: Effects on dry matter intake and milk yield of dairy cows. J. Dairy Sci. 82:589-596.

Oba, M., and M. S. Allen. 1999b. Effects of brown midrib 3 mutation in corn silage on dry matter intake and productivity of high yielding dairy cows. J. Dairy Sci. 82:135-142.

Rao, D. R., G. E. Hawkins, and R. C. Smith. 1973. Effect of glucose and insulin on lipoprotein lipase activity in adipose tissue and milk. J. Dairy Sci. 56:1415-1419.

Robinson, P. H., and R. E. McQueen. 1992. Influence of rumen fermentable neutral detergent fiber levels on feed intake and milk production of dairy cows. J. Dairy Sci. 75:520-532.

Sommerfeldt, J. L., D. J. Schingoethe, and L. D. Muller. 1979. Brownmidrib corn silage for lactating dairy cows. J. Dairy Sci. 62:1611-1618.

Tilley, J. M. A., and R. A. Terry. 1963. A two stage technique for the in vitro digestion of forage crops. J. Br. Grassl. Soc. 18:104-111.

Tine, M. A., K. R. McLeod, R. A. Erdman, and R. L. Baldwin. 2001. Effects of brown midrib corn silage on the energy balance of dairy cattle. J. Dairy Sci. 84:885-895.

Van Soest, P. J., J. B. Robertson, and B. A. Lewis. 1991. Methods for dietary fiber, neutral detergent fibet, and nonstarch polysaccharides in relation to animal nutrition. J. Dairy Sci. 74:35833597.

Weiss, W. P., and D. J. Wyatt. 2002. Effects of feeding diets based on silage from corn hybrids that differed in concentration and in vitro digestibility of neutral detergent fiber to dairy cows. J. Dairy Sci. 85:3462-3469.

Wildman, E. E., G. M. Jones, P. E. Wagner, R. L. Boman, H. F. Troutt Jr., and T. N. Lesch. 1982. A dairy cow body condition scoring system and its relationship to selected production characteristics. J. Dairy Sci. 65:495-501. 